\title{
UNIVERSITYOF
}

FORWARD

THINKING

WESTMINSTER用

WestminsterResearch

http://www.westminster.ac.uk/westminsterresearch

\section{An exploratory analysis of the effects of ownership change on airport competition}

Pagliari, R. and Graham, A.

NOTICE: this is the authors' version of a work that was accepted for publication in Transport Policy. Changes resulting from the publishing process, such as peer review, editing, corrections, structural formatting, and other quality control mechanisms may not be reflected in this document. Changes may have been made to this work since it was submitted for publication. A definitive version was subsequently published in Transport Policy, DOI: 10.1016/j.tranpol.2019.04.004, 2019.

The final definitive version in Transport Policy is available online at:

\section{https://dx.doi.org/10.1016/j.tranpol.2019.04.004}

(C) 2019. This manuscript version is made available under the CC-BY-NC-ND 4.0 license https://creativecommons.org/licenses/by-nc-nd/4.0/

The WestminsterResearch online digital archive at the University of Westminster aims to make the research output of the University available to a wider audience. Copyright and Moral Rights remain with the authors and/or copyright owners.

Whilst further distribution of specific materials from within this archive is forbidden, you may freely distribute the URL of WestminsterResearch: ((http://westminsterresearch.wmin.ac.uk/)).

In case of abuse or copyright appearing without permission e-mail repository@westminster.ac.uk 


\section{Accepted Manuscript}

An exploratory analysis of the effects of ownership change on airport competition

Romano Pagliari, Anne Graham

PII:

S0967-070X(18)30672-3

DOI:

10.1016/j.tranpol.2019.04.004

Reference:

JTRP 2163

To appear in:

Transport Policy

Received Date:

10 September 2018

Accepted Date:

08 April 2019

Please cite this article as: Romano Pagliari, Anne Graham, An exploratory analysis of the effects of ownership change on airport competition, Transport Policy (2019), doi: 10.1016/j.tranpol.

2019.04.004

This is a PDF file of an unedited manuscript that has been accepted for publication. As a service to our customers we are providing this early version of the manuscript. The manuscript will undergo copyediting, typesetting, and review of the resulting proof before it is published in its final form. Please note that during the production process errors may be discovered which could affect the content, and all legal disclaimers that apply to the journal pertain. 
Title

An exploratory analysis of the effects of ownership change on airport competition

\section{Authors}

Romano Pagliari, Cranfield University

Anne Graham, University of Westminster

\section{Acknowledgements}

The authors would like to thank Mr Francois Bourienne, Director Commercial, Glasgow Airport Ltd for his very valuable insights on aeronautical charging, route development and airport competition.

\section{Declaration of Interest}

None

\section{Corresponding Author}

Dr. Romano Pagliari

Centre for Air Transport Management,

School of Aerospace, Transport and Manufacturing,

Martell House,

Cranfield University,

Cranfield MK43 0TR

United Kingdom

E: r.pagliari@cranfield.ac.uk

$\mathrm{T}:$ +44 (0)1234 754231 


\title{
An exploratory analysis of the effects of ownership change on airport competition
}

\begin{abstract}
Common or group ownership of airports poses a particular challenge for policymakers, in that consumers (airlines and passengers) may not have access to benefits that stem from a more competitive system (e.g. lower prices, higher quality of service). However, whilst the arguments for and against group versus individual operations are well known, there are only limited practical cases when a change from common to individual ownership has occurred. One such case is in Scotland where the ownership of Edinburgh and Glasgow airports was separated in 2012. Therefore, the aim of this paper is to undertake a comparative assessment of the impact of this ownership change on the nature of competition between the two airports for the period 20062017. Catchment areas overlap, so it was hypothesised that separate ownership would lead to a more intense competitive rivalry with consequent effects on route development, traffic growth, the level/structure of aeronautical charges, financial performance, capital investment and quality of service. A number of key performance indicators covering these areas have been analysed, both before and after 2012 to assess whether there is evidence of a more competitive environment. The main findings are (i) traffic and routes have increased at both airports, although their relative roles appear to have changed; (ii) published charge levels have increased (iii) aeronautical yield has increased at Edinburgh but declined at Glasgow; (iv) prices have diverged reflecting differences in core market price elasticities; strategies have also been driven by a broader financial imperative around maximising EBITDA given declining unit costs and stagnation in non-aeronautical yields; (vi) certain performance indicators suggest that efficiency and service quality have improved. The implications for policy-makers are that airport market re-structuring and ownership change will most likely lead to divergence in pricing and route development strategies.
\end{abstract}




\section{Key words}

Aeronautical charges; airport ownership change; divestment; airport route development; airport competition; airport financial performance

\section{Introduction}

In some countries, airport systems are largely managed by one operator (e.g. Spain, Norway, Finland). This is in contrast to other countries such as Germany, France and the UK, where there is a greater diversity of ownership and hence potentially more competitive airport markets.

Common ownership of airports poses a particular challenge for policy-makers, in that consumers (airlines and passengers) may not have access to benefits that stem from a more competitive system (e.g. lower prices, higher quality of service), assuming that the operating environment is such that competition between the airports could potentially exist. However, whilst the arguments for and against group versus individual operations have been debated in the literature, there are only limited practical cases when a change from common to individual ownership has occurred. One such case is in Scotland, which is the focus of this research.

In 2009, the former UK competition authority (the Competition Commission (CC)) completed an investigation of the then private operator BAA's common ownership of airports in London / South-East of England and Scotland. The investigation sought to assess whether common ownership had produced adverse effects in these markets in relation to areas such as the level of aeronautical charges, the delivery of capital investment and in the quality and standard of service received by consumers. After two years of extensive research, the Commission concluded that common ownership had indeed produced adverse effects and these materialised around a lack of management responsiveness to airline customers with regard to the delivery of service and capital investment at the London airports and a conviction that the Scottish market would benefit from greater competition on price, service, investment and innovation by 
separating the ownership of Edinburgh and Glasgow airports (Competition Commission, 2009). Consequently, BAA was ordered to divest itself of both Gatwick and Stansted airports in London and either Glasgow or Edinburgh in Scotland. BAA completed its sale of Gatwick in 2009 and BAA's successor entity, Heathrow Airport Holdings (HAH), divested itself of Edinburgh in 2012 and Stansted in 2013.

It has now been six years since Edinburgh was sold to the US-based Global Infrastructure Partners (GIP). This provides a reasonable time frame to compare the impact of divestment on the operations and financial performance of both Edinburgh and its closest competitor Glasgow. There is considerable substitutability between these airports, and so there was an expectation that competition would develop between them in the absence of common ownership. Therefore, this paper aims to assess the overall impact of ownership change on competition by focusing on five important dimensions: traffic growth, airline and route choice, aeronautical charging, financial performance and efficiency, and service quality. By considering these five dimensions, conclusions will be drawn as to the extent to which the airports engaged in competitive rivalry and whether there are any subsequent policy implications. The analysis focuses both on the overall performance before and after 2012 to assess whether there is evidence of a more competitive environment.

The structure of this paper is as follows. The next section provides a brief discussion of the background context and literature related to airport competition. This is followed by an explanation of the methodology and the data sources used. The analysis is presented in Section 4 and the paper concludes with a summary of the findings and a discussion of the policy implications.

\section{Background context related to airport competition}

In recent years there has been a significant change in the extent of competition that exists within the airport industry (Forsyth et al., 2010). This has been driven partly by airline deregulation and liberalisation, which has removed barriers to entry facilitating more potential and actual competition between airlines and, as a result, between airports as well. This has also created deeper structural changes across the airline 
industry such as the formation of global alliances and the emergence of low-cost carriers (LCCs), which rely on the use of certain airport business models as part of their competitive strategy. At the same time, the move towards the commercialisation and privatisation of the airport industry has meant that operators have become much more business and market-orientated in seeking new, or retaining existing, customers. In practice, airport competition can occur in a number of different circumstances, most commonly when hub airports compete for transfer traffic, or when airports have overlapping catchment areas, either in a city or a metropolitan region (particularly if secondary airports are chosen as alternatives), or with neighbouring regional airports. In these cases, the airports in question can be considered as substitutes for airlines and passengers.

Specifically, within Europe, there has been considerable debate as to the actual degree of airport competition. Lieshout et al. (2016) argued that airport (and airline) competition varies within Europe, being strongest in the UK, Benelux, Western Germany, Switzerland and Northern Italy. In various reports commissioned or written by the Airports Council International $(\mathrm{ACl})$ Europe, it has been strongly argued that a relatively high level of competition exists (Thelle et al., 2012; ACI-Europe, 2014; Oxera, 2017; ACl-Europe, 2017). Such views have been vehemently challenged by certain airlines and the International Air Transport Association (IATA) (e.g. IATA, 2013). Thelle and Sonne (2018), in support of the general airport industry position, argued in favour of the relaxation of competition constraints associated with economic regulation. Meanwhile Wiltshire (2018), in defending the airline position, challenged the $\mathrm{ACl}$ argument, claiming that there is only limited competition in the airport sector and that this justifies the continuing need for robust economic regulation. This demonstrates the important implications of the existence of airport competition in terms of regulatory policy (Forsyth, 2006) and aeronautical pricing (Botasso et al., 2017).

Such differing opinions arise partially because the existence of increased airport competition can be assessed in a number of different ways. Some of these have been explored more in the literature than others. Firstly, traffic and route development can 
be considered. Strong growth in traffic can indicate airport rivalry in seeking to encourage airlines and their passengers to fly more frequently. New airlines and new routes can provide passengers with more airport choice. This means that the switching of passengers or airlines between different airports can help demonstrate the true substitutability of competing airports. This may involve airlines cutting services or abandoning airports entirely. Indeed, it has been argued that such 'route churn' has been increasing in Europe, particularly in relation to LCCs (De Wit and Zuidberg, 2016).

Secondly, airport competition can have an impact on aeronautical charges, with the logical assumption being that increased competitive pressures will drive down prices and produce declining airport yields. There is evidence in both the US (Van Dender, 2007) and in Europe (Bel and Fageda, 2010) of lower aeronautical charging when airports face competition from neighbouring airports. Additionally, increased competition may manifest itself in changes to charging structures, bespoke agreements or contracts with individual airlines, or in the existence of incentives for new or expanded services (Halpern and Graham, 2016). Such arrangements will not normally be apparent by looking at the airport's published charges. These symptoms of competition all appear to have become increasingly more common across Europe in recent years (Fichert and Klophaus, 2011; Jones et al, 2013; Malina et al, 2012). In fact, only $16 \%$ of European airports are estimated not to offer either incentives or individual contracts according to ACI Europe (2015).

Thirdly, it can be argued that greater airport competition can lead to improvements in efficiency and economic performance. However, evidence here is mixed. For example, Scotti et al. (2012) found that the intensity of competition had a negative impact on airports' efficiency in Italy, whereas in China and North East Asia the impact was found to be positive (Chi-Lok and Zhang, 2009; Ha et. al, 2013). Airports in a competitive environment could perhaps also be more innovative in their approach to non-aeronuatical revenue generation and in planning investment. However, Adler and Liebert (2014) argued that the impact of competition on airport performance cannot be 
considered by itself, and instead they considered it jointly with ownership form and economic regulation.

Finally, it can be argued (e.g. OECD, 2014) that improvements in service quality can indicate a more competitive airport environment as rival airports try to attract more airlines and passengers, and possibly at the same time aim to improve operational efficiency. However, whilst service quality is an area that has been given increasing attention in the literature (Lee and Yu, 2018; Bezeera and Gomes; 2016) detailed analysis of its relationship with competition has rarely been made.

As already highlighted, the ability of airports to compete is particularly an issue when there is the existence of a group or network of airports being managed by one single operator, especially if there is a substantial degree of catchment area overlap between the airports. $\mathrm{ACl}$ (2017) estimated that globally $69 \%$ of countries have national network ownership models. It has been argued that operating as a group may achieve economies of scale, allow for the best use of resources and expertise within the airport group, and enable a more strategic co-ordinated approach to master planning. On the other hand, group ownership could inhibit competition and limit incentives to react to the needs of individual airport users and to provide capacity where it is needed (Graham, 2018).

There are only a few examples of airport separation from group ownership and management. For instance, in Ireland, when Shannon airport was separated from the airport operator DAA (which also owned Dublin and Cork) in 2013 and in Sweden, when state-owned Swedavia sold ten small regional airports to their respective local municipalities. A common feature of many airport groups is that they contain a few large international airports that are profitable, and clusters of small regional or local airports that are not. This raises issues concerning the continued viability of the smaller airports and the need for cross-subsidisation that can be particularly challenging when such airports are being privatised, as in the case, for example, of Portugal (Marques, 2011). As a result, overall privatisation practice has varied. In countries such as Argentina, Portugal and Spain, airport groups have been privatised 
in their entirety as single networks, whereas in Australia all the major airports which were part of the Federal Airports Commission were sold to investors in separate transactions. In Mexico, the airport system was divided into four different groups consisting of combinations of small and large-sized airports (Graham, 2018). Within this context of making complex privatisation decisions concerning airport groups, Socorro et al. (2018) argued that it is not just whether competition is feasible that should be considered, but also whether it is desirable from the perspective of the national interest.

In the United Kingdom, after much debate, BAA was privatised in 1987 as a single entity, but this remained a controversial issue and subject to several governmental reviews investigating whether it should be split up. These generally concluded that the additional benefits of competition would be more than offset by the dis-benefits manifested in the loss of economies of scale, fragmentation of the combined financial strength of the group and the dispersion of technical and managerial expertise (Toms, 2004). BAA was then investigated again by the Competition Commission in the late 2000s (Competition Commission, 2009; Bush 2009). Its main conclusion was that common ownership of airports in South-east England and Lowland Scotland did give rise to adverse effects on competition in connection with the supply of airport services by BAA (albeit that with the London airports it identified other features such as planning and economic regulation that could potentially have an impact on competition as well). Consequently, as mentioned above, BAA was required to divest some of its airports; completing its sale of Gatwick in 2009, Edinburgh in 2012 and Stansted in 2013.

In 2016, the successor to the Competition Commission, the Competition and Markets Authority (CMA), with the help of the consultants ICF, undertook a detailed assessment of the effects of such divestment (CMA 2016; ICF 2016). It identified a number of factors that indicated increased competition at the three airports since divestment, such as greater passenger growth than at other airports with increased efforts to attract new airlines. It also observed that the airports had altered the structure of their charges to airlines in order to become more competitive. In addition, it found increases in both capital investment and operational efficiency at the three airports. 
Moreover, it concluded that service quality had improved markedly at the first divested airport Gatwick, and similar enhancements were expected at Stansted and Edinburgh once a number of changes had become fully embedded.

However, this analysis focused on all three divested airports and in assessing the performance of Edinburgh airport, only limited attention was given to Glasgow. Hence it is the aim of this research to fill this gap, with a comparative analysis of Edinburgh and Glasgow, before and after divestment. Moreover, the CMA analysis with a publication date of 2016 was quite limited with the time period that was considered. The analysis in this paper, although having a similar approach, provides a more upto-date assessment which has enabled observation and analysis over a longer timeframe.

\section{Methodology and data sources}

Leading on from this background context, five key areas have been selected to assess the impacts of ownership separation. These are identified in Table 1 with the data sources used.

\section{Analysis areas 2006-2016/17 (financial values in real terms)}

1. Traffic development:

Total, domestic, EU and non-EU passenger growth

\section{Airline and route choice:}

Number of destinations

Route churn

\section{Aeronautical charging:}

Landing charges

International and domestic passenger charges

Aeronautical revenue per passenger

4. Efficiency and financial performance:

Non-aeronautical revenue per passenger

Operating expenditure (Opex) per passenger

Earnings before interest, tax depreciation and amortisation

(EBITDA) margin

5. Service quality performance:

Capital expenditure (Capex)

Capex per passenger

$\mathrm{ACl} A S Q$ passenger satisfaction scores

On-time performance

\section{Data sources}

CAA airport statistics

OAG schedule data

Published airport charges from the airport's websites

Airport annual reports

Airport annual reports

Airport annual reports

ICF (2016)

CAA punctuality data

\section{Table 1: $\quad$ Analysis areas and data sources}


One of the major challenges is in isolating the impacts that are due to divestment compared to other factors. Ideally, some econometric analysis of the indicators in Table 1 with possible drivers (including divestment) should be undertaken. Numerous wider and external factors related to both the airports and airline markets such as the global recession, fuel prices, technological innovations, changing airline structures (e.g. partial convergance between LCC and full service carrier models, airline consolidation and bankruptcies), as well as specific developments related to the demand characteristics, passenger preferences and catchment areas of the two airports, could have influenced how the performance indicators have evolved over the period of analysis. However, the quality and volume of the data, particularly given the relatively short time period since the sale of Edinburgh, makes this research proposition quite challenging and problematic. Hence it was not possible to control for these external factors with an econometric approach and so instead the analysis focuses on building up a unique and preliminary evidence base that offers significant insight into developments at the two airports and how this could have been influenced by ownership separation. This can then be further developed with future research when data sets may be more extensive.

Prestwick airport, which also serves the Glasgow area is excluded from the analysis (except when examining passengers numbers) because of the very different business model that has been adopted at this airport. Moreover very little financial information is available, especially as ownership was transferred to the Scottish Government in 2013. Furthermore, a comparison of published aeronautical charges would be an unreliable indicator of pricing strategy given that the main airline Ryanair was understood to have negotiated its charges under a separate contract with the airport.

\section{Main findings of the research}

\subsection{Introduction to the two airports}

The airports are separated by a distance of $77 \mathrm{~km}$. They are connected by the M8 motorway which links the cities of Glasgow and Edinburgh, with populations of around 600,000 and 450,000 respectively. Both airports also a serve a wider catchment area 
that covers towns and cities in the Central Scotland metropolitan region which amounts to a total population of around 4 million.

There is extensive overlap of the airport catchment areas with Glasgow being by far the closest substitute airport geographically to Edinburgh, while Edinburgh is the second closest substitute airport (after Prestwick) to Glasgow (Competition Commission, 2009). Edinburgh is the largest of the two airports, handling 13.4 million passengers in 2017 compared to 9.9 million at Glasgow. This Scottish Lowland market is also served to a lesser extent by Prestwick airport (handling 0.7 million passengers in 2017), located approximately $64 \mathrm{~km}$ to the south of Glasgow airport, but as already discussed, this and other Scottish airports are excluded from the analysis. Edinburgh airport also enjoys accessibility advantages over its rival. The airport is located to the west of the City of Edinburgh making it closer and more accessible to the city of Glasgow and its metropolitan region. In contrast Glasgow airport is located to the west of Glasgow making it less accessible to residents of Edinburgh and East-central Scotland.

Historically, Glasgow was the busier of the two airports in passenger volume terms, being the gateway of choice for international carriers, especially following the termination of official traffic distribution rules in 1990 which had limited Scottish transatlantic services to operating out of Prestwick. For a long period after this change, Glasgow functioned as the largest airport in Scotland and as the preferred Scottish gateway for international services. Edinburgh airport's prospects started to improve from 1998 following the establishment of the Scottish Parliament (based in the capital Edinburgh) which in effect led to a shift in the balance of economic and political power between both cities. In 2007, Edinburgh eclipsed Glasgow to become the busiest airport in Scotland.

Even though there is considerable catchment area overlap, both airports serve very different core markets. In addition to functioning as the administrative and political capital of Scotland, Edinburgh acts as a significant centre of banking and finance as well as hosting several internationally recognised and popular tourist attractions. 
Glasgow, which is a larger city in terms of population, nonetheless has a weaker catchment area in air travel propensity terms. Its hinterland used to depend on heavy industries and a substantial manufacturing activity that have since declined, leaving behind an economic legacy of higher than average unemployment, lower disposable income and a greater level of social deprivation. As a result, Glasgow airport has always had a much higher percentage of leisure traffic than Edinburgh. In 2013 UK resident leisure travel accounted for $63 \%$ of passenger traffic at Glasgow but only $47 \%$ at Edinburgh (CAA, 2014).

Evidence from the CMA review and other sources confirms that BAA was considered to have encouraged this segmentation between leisure traffic at Glasgow and business traffic at Edinburgh, offering no real incentives to develop competition between the two airports because of the significant overlap in catchment areas. Marketing was primarily undertaken at a Scottish level with little focus on selling the relative advantages of the different airports.

\subsection{Traffic Development}

Reference to traffic trends between 2006 and 2017 (Figure 1) shows that Edinburgh's market appeared to be much more resilient to the effects of the 2008-2009 financial crisis than Glasgow, where there was a more pronounced contraction in traffic volume, primarily due to its greater dependency on the outbound leisure passenger market segment. However, since divestment, both airports have experienced significant growth, tentatively suggesting that there is stronger rivalry between them. Overall Edinburgh has increased its market share of the Scotland Lowland area (as noted in 2007 Edinburgh displaced Glasgow as Scotland's busiest airport) whilst Prestwick now only holds onto a marginal share of this market. 


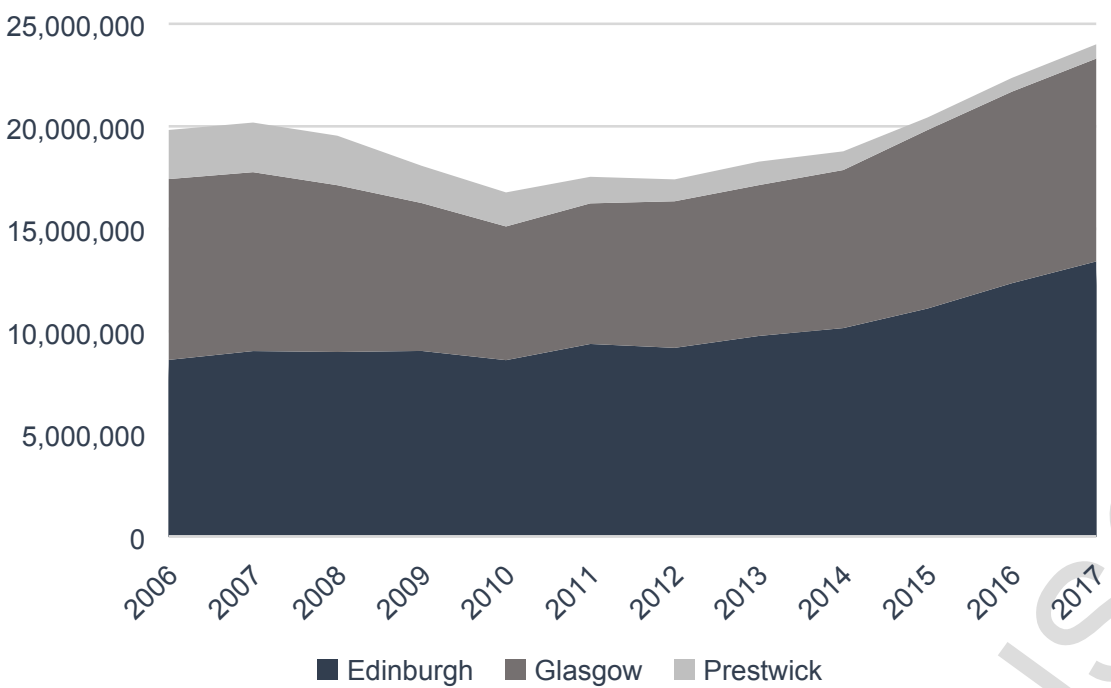

Figure 1: Terminal passengers at Scottish Lowland airports 2006-2017 Source: UK CAA

International traffic accounts for a higher percentage of total passenger volume at Edinburgh and Glasgow airports. Volumes of domestic traffic have declined between 2006 and 2017 but this has been more than offset by much faster growth in international EU traffic for both airports both before and after divestment. Moreover, Edinburgh's growth in the non-EU markets has been particularly notable which is discussed below (Figure 2).

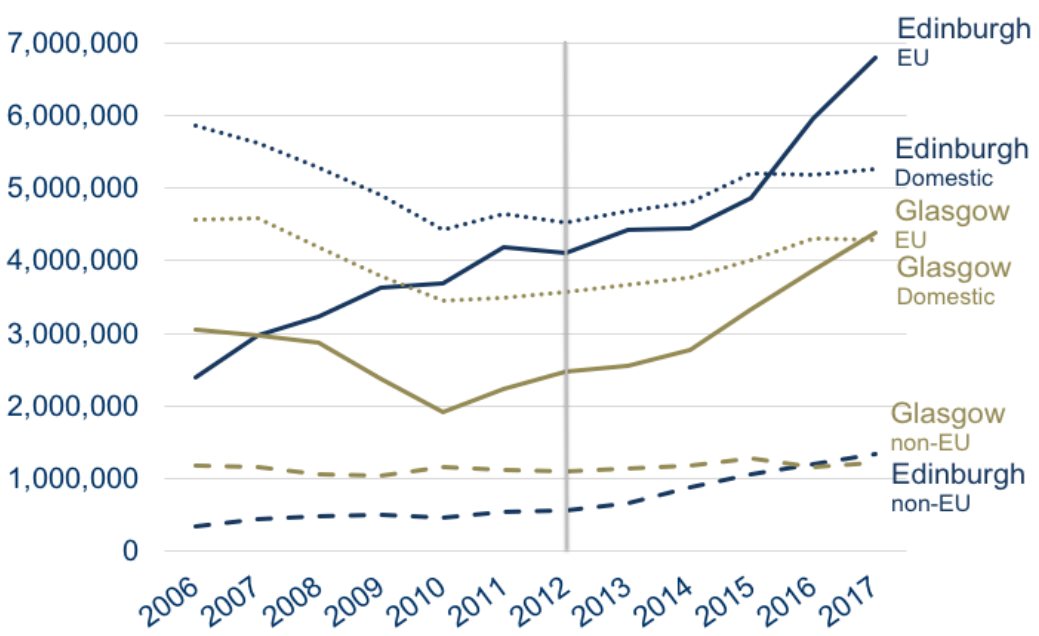

Figure 2: $\quad$ Terminal passengers by market at Edinburgh and Glasgow airport 2006-2017 Source: UK CAA 
It is important to note that at Edinburgh airport in $2006,96 \%$ of traffic was carried on scheduled services as opposed to charter flights. By 2017 , this had increased to $98 \%$. In contrast, charter operations have always accounted for a higher proportion of traffic at Glasgow (9\% in 2017) - although there has been a marked decline in the charter sector's share of traffic from a level of $22 \%$ in 2006 . This trend is symptomatic of a much wider structural development in the charter sector which has experienced significant loss of market share to LCCs and may well not be linked to the changing ownership structures.

\subsection{Airline and route choice}

As already identified, the nature and composition of international traffic at the two airports has traditionally been quite different. Glasgow's international market has been dominated by LCC services and some holiday charter airline operations to destinations in short-haul European markets with the airport struggling to maintain full service carrier services to major hub airports. In contrast, Edinburgh has been much more successful and resilient in the network carrier market, securing a wider range of hub feeding services. Easyjet and Ryanair have developed extensive short-haul international connections from both airports. After 2008 but starting before Edinburgh's divestment, Ryanair gradually expanded its Glasgow operations having originally preferred the smaller and cheaper Prestwick airport. However, in 2018, the airline took a decision to transfer a significant proportion of its Glasgow operations to Edinburgh, which has also established itself as the preferred Scottish gateway for nonUK-based low-cost airlines (Norwegian, Germanwings, Transavia and Vueling).

In the transatlantic market, Glasgow traditionally functioned as the Scottish airport of choice for US carriers such as United, and American/Delta (seasonal), encouraged by BAA's wish to use excess capacity at Glasgow. In terms of other long-haul markets, Emirates also selected Glasgow ahead of Edinburgh when regular services were launched to Dubai in 2003. United established its first transatlantic services link from Edinburgh in 2004. This was followed by the launch of new services by Delta, American and Air Canada Rouge after 2012. Furthermore, new direct links to Gulf 
hubs in the Middle East were added by Qatar and Etihad in 2015. In 2016 Edinburgh airport had 14 long-haul routes compared with just one (New York Newark) before divestment and in the summer of 2018 the first direct service to Beijing was launched. The increase in non-EU passengers and long-haul routes at Edinburgh could be interpreted as Edinburgh becoming more competitive in such markets not previously considered by the airport before divestment. Indeed, on the airport marketing website for 'The Route Shop' 13 long-haul routes that Edinburgh wishes to attract are identified compared to just three on the Glasgow page. Interestingly, on the Edinburgh page, there is comparative information regarding surface access at Glasgow highlighting why Edinburgh airport is superior (Route shop, 2018).

Figure 3 shows that the number of domestic destinations at both airports has remained relatively stable throughout the period. Edinburgh, however, has enjoyed much faster growth in international destinations, especially before ownership divestment. Glasgow, in spite of having fewer international connections, nonetheless achieved a faster growth rate post-2012. Of particular relevance is the fact that in $2006,37 \%$ of Edinburgh's destinations were also served with links to Glasgow - this increased to $59 \%$ in 2017. Likewise, in 2017 Glasgow shared $53 \%$ of its destinations with Edinburgh compared to $48 \%$ in 2006 . Thirty-two routes were served by both Glasgow and Edinburgh in both 2006 and 2017 but by 2017 there were also 21 additional shared routes. This increased overlap of services at the two airports could arguably be seen as another sign of increased competition between the two airports.

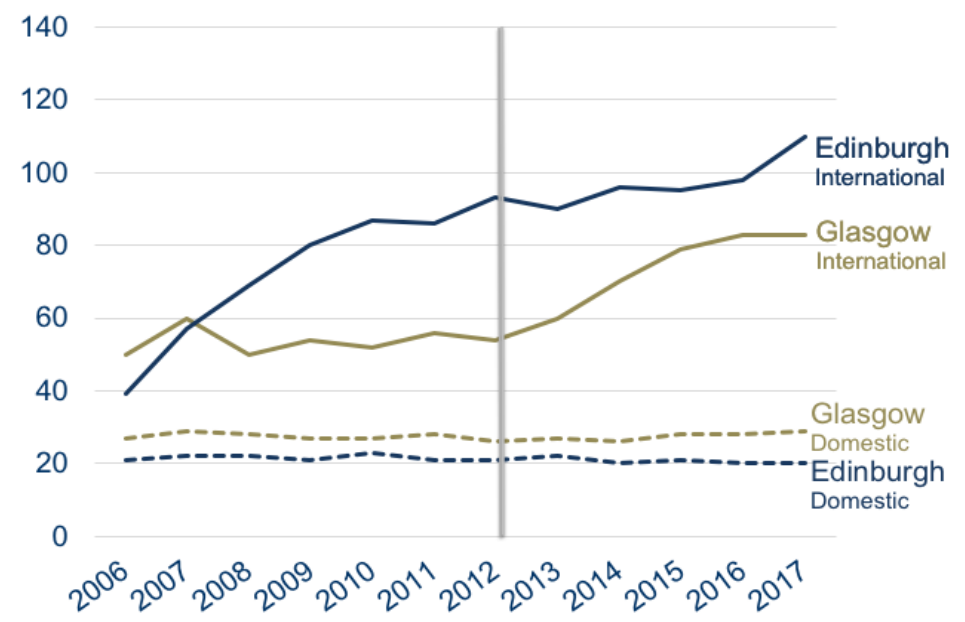


Figure 3: $\quad$ Number of destinations by market at Edinburgh and Glasgow airport 20062017

Source: Flight Global OAG Analyzer

However, as discussed earlier, increased competition does not necessarily lead to significant changes to the total number of routes at each airport. Instead, it may merely lead to more routes being added and lost at a greater rate, i.e. an increase in route churn. Figure 4 and 5 show the situation at the two airports in terms of route churn. In both cases there seems to be a considerable degree of churn (suggesting a competitive situation) although not a noticeably higher amount since 2012.

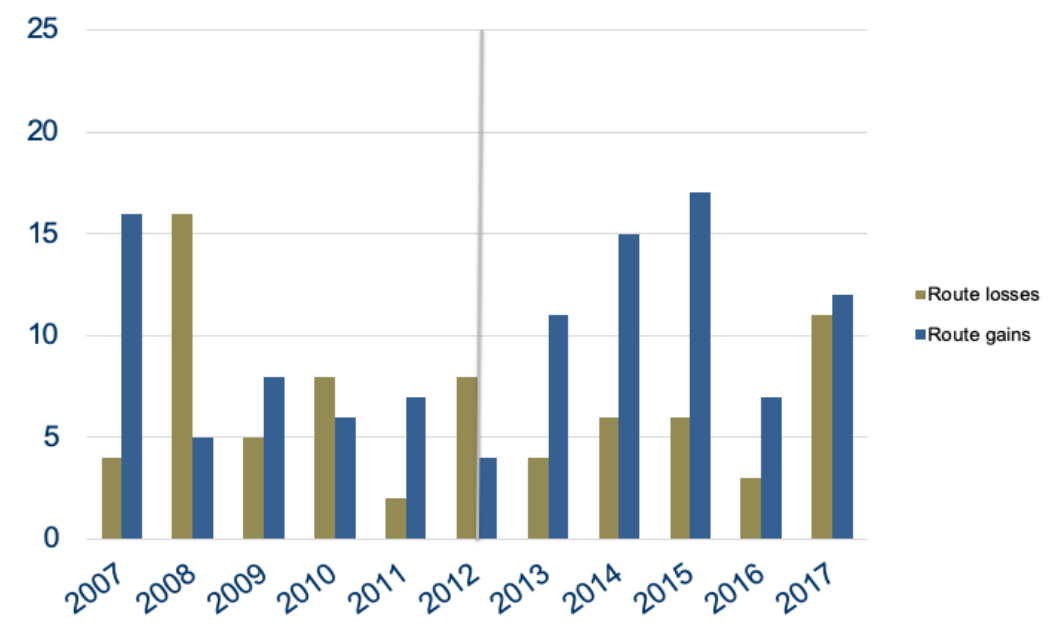

Figure 4: $\quad$ Route churn (entry and exit of routes) at Glasgow Airport 2007-2017

Source: Flight Global OAG Analyzer

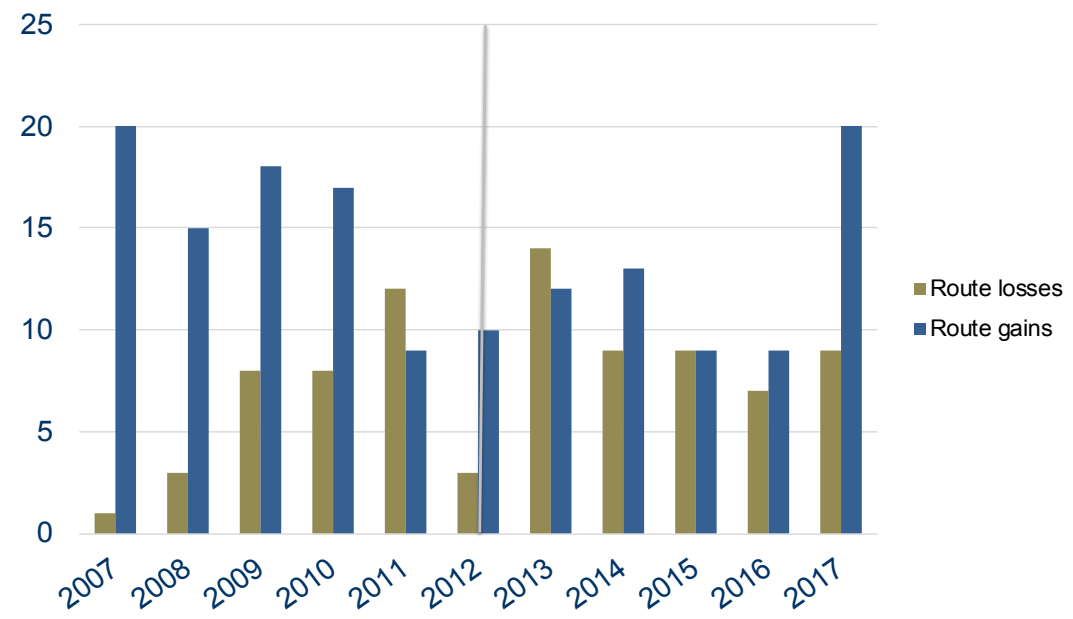

Figure 5: $\quad$ Route churn (entry and exit of routes) at Edinburgh Airport 2007-2017 Source: Flight Global OAG Analyzer 
An important dimension in the route development narratives of both airports, especially in the period prior to separation, has been the influence of the Scottish Government's own route development fund which operated between 2003 and 2007 . The Route Development Fund reflected a realisation that Government support was needed to encourage connectivity growth through offering airlines financial incentives to establish new services. This initiative was complemented by a stronger BAA-led route development initiative that was established at around the same time. Pagliari (2005) credited BAA with route development successes at least in the initial period of the fund's operation more so than the Government's route development which he argues had been much less effective. This is in contrast to the findings of Smyth et al. (2012), who through an analysis of the entirety of the fund's operations, argued that it was much more effective in its role in supporting route development and improved regional connectivity. Whilst the fund is no longer available in Scotland (Sunday Herald, 2015), Transport Scotland recently stated (Transport Scotland, 2018):

'There are a number of previous examples of our successful partnerships with airports, including Edinburgh's services to the Middle East, which were introduced in 2014 and 2015. It also has a venture with Norwegian Air Shuttle in 2017, which will open up 3 new destinations to the US. We worked with Glasgow Airport to deliver new Canadian connections in 2015 and 2016 and a New York JFK service beginning in 2017.'

Consequently, this makes it difficult to isolate the effects of both the marketing efforts of the individual airports and the financial help provided by Transport Scotland.

\subsection{Aeronautical charges}

It has been hypothesised that following ownership separation, aeronautical charges would become more competitive. Prior to 2012, the charging structures adopted at Edinburgh and Glasgow were very similar under BAA ownership. After divestment, these structures started to deviate (actually immediately following the $\mathrm{CC}$ decision) but this is particularly evident in changes that were adopted from 2017 when Edinburgh introduced some fundamental alterations to its passenger charges, which are by far 
the most important in revenue terms. In order to deal with congestion caused by higher traffic volumes particularly in summer months, the airport introduced a passenger charge structure that included per passenger unit rates differentiated by peak months, shoulder months and off-peak months. High traffic throughput during the morning departure peak, appears to have also prompted the airport to levy a peak-time premium of $£ 200$ on flights departing during this period; although in terms of scale, this additional charge was relatively insignificant. However, airlines operating during the summer months faced a 19\% increase in the passenger charge between 2016 and 2017. Arguably such changes in charges could have resulted from increased commercial pressure to become more efficient, make better use of resources and cope with congestion.

By contrast Glasgow airport, which has traditionally faced a greater degree of traffic seasonality (mainly due to summer outbound holiday demand peaking), had always applied a seasonal passenger charge differential. However, over time, this differential has narrowed. In 2007, flights operating in the summer season were subject to a passenger charge that was $22 \%$ higher than in winter; by 2017 , this had narrowed to $9 \%$. Furthermore, in 2017 , the time period where airlines could qualify for the discounted charge was changed from the full November-March scheduling season to a narrower time frame restricted to January and February. In 2018, the Glasgow seasonal differential had been removed completely. The implications are clear, Glasgow appears to have adopted a different strategy from Edinburgh by setting out to achieve an improvement in its aeronautical revenues, not only by raising charges faster than the rate of inflation, but also by narrowing both the price differential and the scope of the off-peak period.

Comparisons have been made of the costs accrued in airport charges from an aircraft turnaround operation based on an Airbus A320 service operated by Easyjet with an assumed load factor of $85 \%$ and parking time on stand of 60 minutes. Both airports levy a unit rate landing charge based on maximum take-off weight of the aircraft; at Edinburgh it is slightly higher. Airlines pay parking charges which are based on a unit rate per 15 minutes. The passenger charge is by far the most important and there 
are separate per passenger rates for international and domestic departures. Terminal area navigation services are out-sourced but the airports pass on the costs to the airlines. Other smaller charges cover PRM (persons of reduced mobility), baggage and security.

The comparisons show that landing charges at both airports are the second most important, accounting for between $10 \%$ and $15 \%$ of total costs. Figure 6 compares the landing charge levied at both airports over the period 2006 to 2018 . Over this period, there is very little difference in the landing charge unit rate between both airports. In real terms there is a decline from 2006 to 2012 and then following divestment there is a continuous rise in unit rates at both airports with a modest level of discounting by Glasgow post-2015. Interestingly, this shows that at least in terms of the landing charge, prices in real terms declined during common ownership and then increased following Edinburgh's sale in 2012.

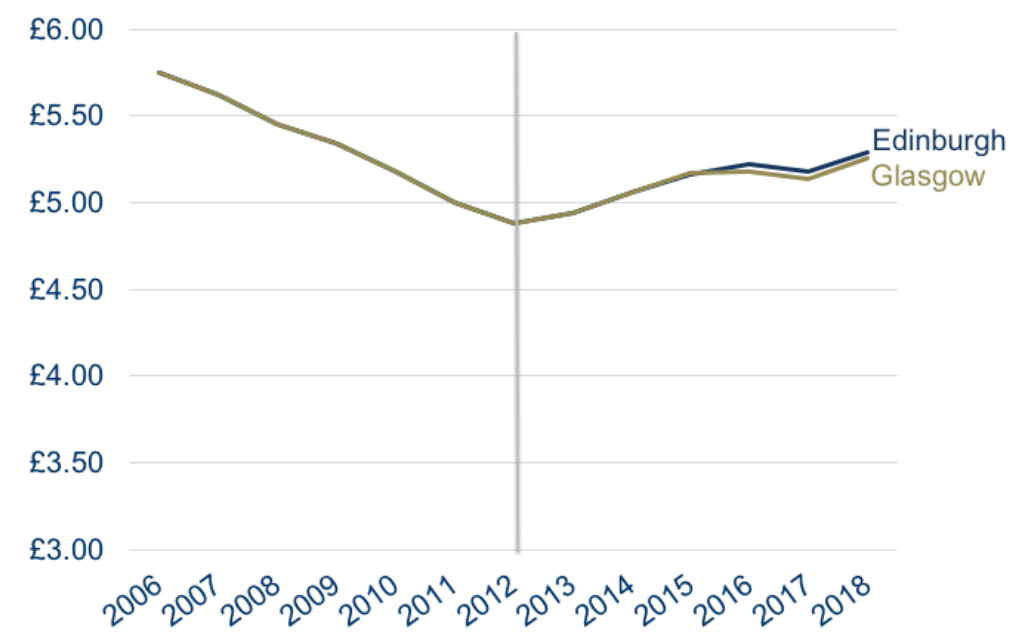

Figure 6: $\quad$ Landing charge per tonne of MTOW at Edinburgh and Glasgow airports 2006-2018 (2016 prices)

Source: Glasgow and Edinburgh airport conditions of use documents 2006-2018

As already mentioned, the passenger charge is, by far, the most important charge levied by both airports. It is here where one can observe a very distinct charging strategy and marked deviation between the airports in the unit rates set for both international and domestic flights. As far as the international passenger charge is concerned, there is a notable real-terms reduction at both Edinburgh and Glasgow 
airports between 2006 and 2012 by $13 \%$ and $14 \%$ respectively. The domestic charges at both airports decline at a lower rate to 2011 followed by an increase at both airports to 2012 (Figure 7).

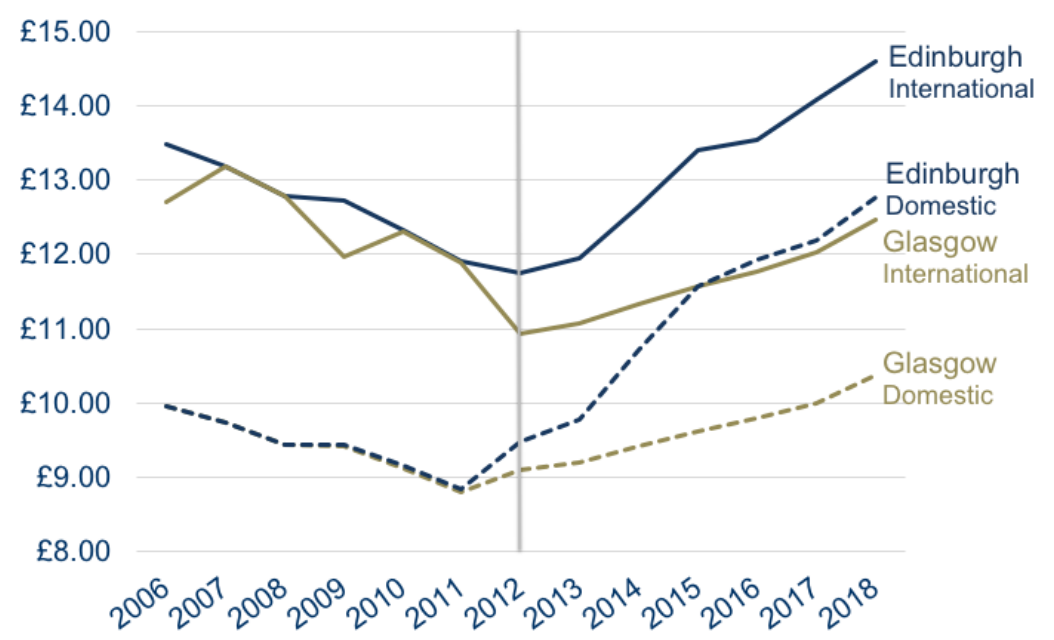

Figure 7: International and domestic per passenger charge at Edinburgh and Glasgow airports 2006-2018 (2016 prices) Source: Glasgow and Edinburgh airport conditions of use documents 2006-2018

The general reduction in real terms passenger charges levels prior to 2012 is interesting. It is obvious that there was a conscious decision to maintain similar charges rates between both airports during this period. There is a sharper reduction in the international passenger charge at Glasgow, possibly as a reaction to weaker market conditions following the 2008 financial crisis. Other than that, charges there were broadly in line with those levied at Edinburgh. Although both airports were under common ownership, regulatory authorities had judged there to be a limited risk of an abuse of market power. Indeed, BAA itself had taken a conscious decision to impose on itself a voluntary price-cap of RPI- $3 \%$ on aeronautical charges at its Scottish airports to lower the risk of future regulatory intervention in the form of a formal price control regime as had existed for many years vis a vis the London airport system (Competition Commission, 2009). This may partly explain the real-term reduction in charges observed between 2006 and 2012.

Since 2012 charges have increased at both Edinburgh and Glasgow. This may seem a little surprising given that there was an expectation that greater competition could 
lead to lower charges. However, the charging levels, especially with regard to both international and domestic per passenger charge, have deviated substantially with charges rising at a much faster rate at Edinburgh compared to Glasgow. This is especially with regard to the domestic charge which increased by a factor of $35 \%$ in real terms since 2012. The trajectory of these charging trends suggests that the airports have recognised the significant differences in price elasticities that exist in their respective markets. Edinburgh charge increases appear to have had no adverse impact on the robust and sustained traffic growth that they had experienced since 2012. This suggests that air carriers are willing to pay higher charges given what would appear to be much more appealing yield opportunities relative to Glasgow. Glasgow, in contrast, recognises its much weaker and more price-elastic market conditions and has therefore discounted its charges relative to Edinburgh in the expectation that it can stimulate traffic growth and perhaps tempt airline customers away from Edinburgh. Another factor explaining Glasgow's pricing strategy is the role of Prestwick. Although excluded from most of the analysis for reasons outlined above, it is possible that there would be a persistent threat facing Glasgow that airlines could transfer their operations in response to a pricing strategy that more closely matched levels set by Edinburgh. However, it should be noted that since 2008, Prestwick itself has experienced much weaker market conditions and consequently the loss of a significant volume of its services to Glasgow after some LCC airlines had made a conscious decision to switch operations. So perhaps since 2012, there was a reduced level of risk that Glasgow could lose traffic to Prestwick.

The analysis thus far has focussed on published charges. However, many airlines do not pay the published rates, but enter into negotiated agreements, that involve a sharing of risk between the airport where charges are linked to incentives around the airline's delivery of traffic and capacity volume as discussed previously. Average aeronautical revenue per passenger otherwise known as aeronautical yield is perhaps a more accurate measure of price. This represents the average price that is paid by all operations at an airport by dividing the total aeronautical revenue in a financial year by the number of traffic units (passengers or air transport movements). However, it is 
important to recognise that one of the limitations inherent in the yield method is that movement over time will not only reflect alterations in pricing policy but equally shifts in the mix of traffic serving an airport and possible strategies designed to differentiate between routes, airlines and passengers that the airport may wish to attract.

Figure 8 contrasts aeronautical yield between both airports over the period. This does show some degree of consistency with the analysis of fixed published charges. Average yield, as in the case of fixed charges, is higher at Edinburgh compared to Glasgow, especially post 2012. Whilst published tariffs declined in real terms between 2008 and 2010, aeronautical yield, in contrast, increased at both airports. This period also coincided with reductions in traffic volumes at both airports, especially Glasgow which experienced a 21\% fall in passenger traffic between 2007 and 2011 which can partially explain the higher aeronautical yield (especially since some charges are not dependent on passenger numbers).

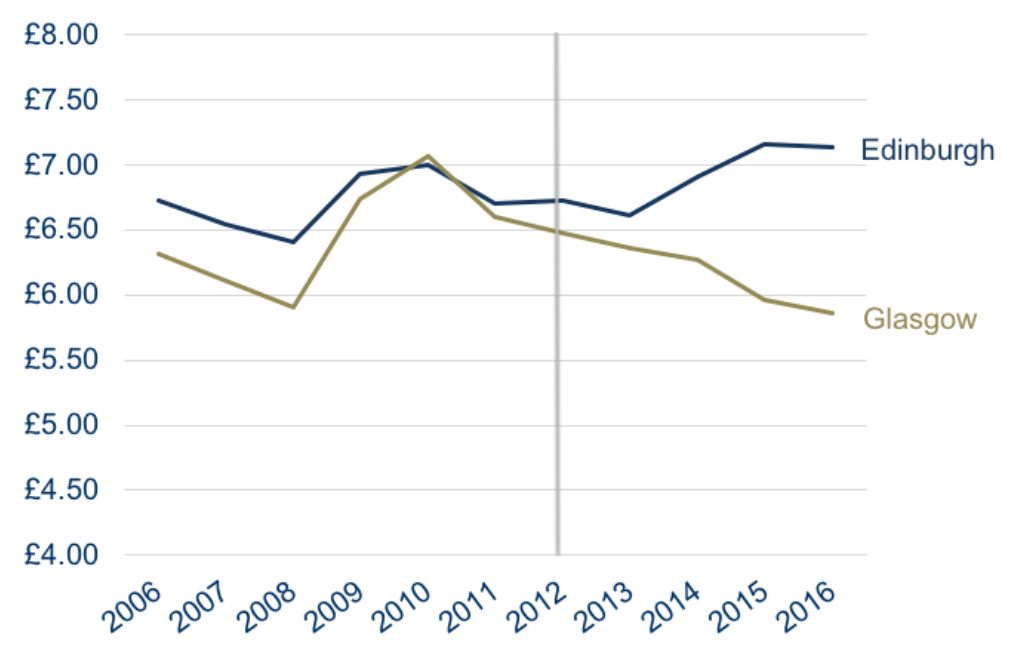

Figure 8: Average aeronautical revenue per passenger (2016 prices) at Edinburgh and Glasgow airports 2006-2016 (2016 prices) Sources: Annual reports and accounts for Glasgow International Airport Ltd and Edinburgh International Airport Ltd 2005/6 to 2016 and CAA airport traffic statistics 2006 to 2016

Following Edinburgh's divestment, yield trajectories diverge quite markedly. By 2016, Edinburgh's aeronautical yield is 6\% higher in real terms compared to 2012; Glasgow's in contrast is $9.5 \%$ lower. This confirms that both airports pursued very different 
aeronautical pricing strategies post-2012 which again seems largely a reflection of divergent price elasticities in their respective traffic markets.

\subsection{Efficiency and economic performance}

As discussed earlier greater airport competition may also be reflected in improved efficiency and airport economic performance. In addition, an analysis of pricing strategy is limited unless there is some recognition of the wider financial context facing both airports.

To start with, Figure 9 compares non-aeronautical yield at both airports. Nonaeronautical revenue yield is a function of many variables of which type of traffic is one of the most significant. Glasgow's higher yields could in a large part be due to the fact that at least up to 2009, international and leisure traffic accounted for a much higher proposition of passenger volumes compared to Edinburgh. However, traffic structure alone cannot account for subsequent growth trajectories in non-aeronautical yield since Edinburgh's significant acceleration in international traffic does not appear to have much effect on non-aeronautical yield. Under shared ownership, BAA had a common approach to contracts but consequently Edinburgh airport in particular has now developed new strategies in this area and increased its retail space (CMA, 2016). In spite of this, the relatively disappointing levels of growth in non-aeronautical yield at Edinburgh and indeed Glasgow, merely reflect general trends of flat or even declining non-aeronautical yields at European airports generally; overall, they have declined by nearly 5\% since 2011 (ACl-Europe, 2018). This perhaps provides some indication of why both airports have sought to leverage more revenue growth from higher aeronautical charges. 


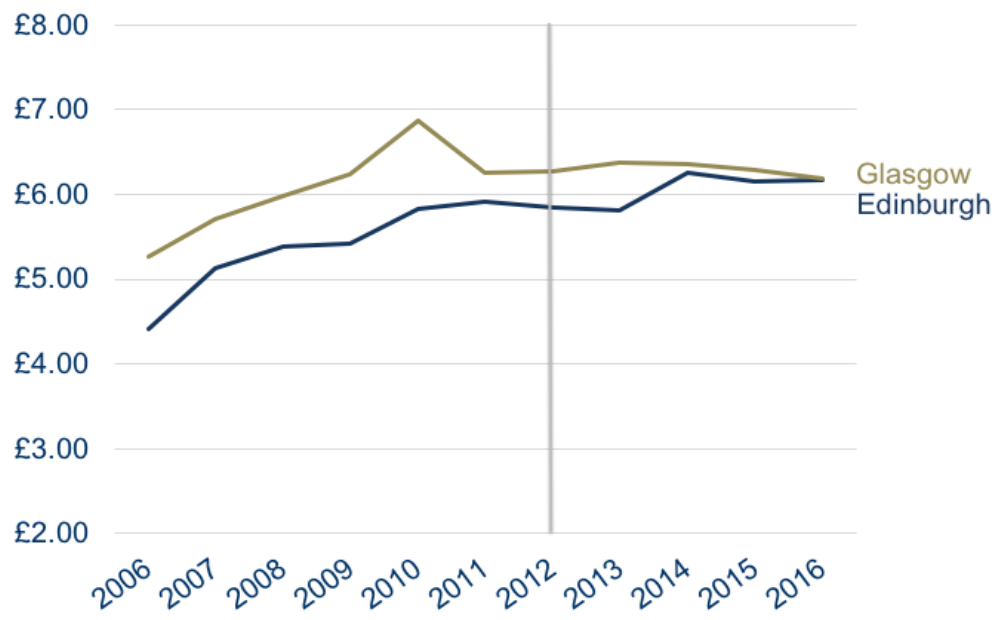

Figure 9: $\quad$ Non-aeronautical revenue per passenger (2016 prices) Edinburgh and Glasgow airports 2006-2016 (2016 prices)

Sources: Annual reports and accounts for Glasgow International Airport Ltd and Edinburgh International Airport Ltd 2005/6 to 2016 and CAA airport traffic statistics 2006 to 2016

Changes in operating cost will also potentially have an effect on aeronautical pricing strategy, especially in circumstances where there has been a signifcant increase which cannot be soley recovered from non-aeronautucal sources, and additionally they can indicate greater competitive pressures between the two airports to become more efficient. Figure 10 compares operating cost per passenger over the period.

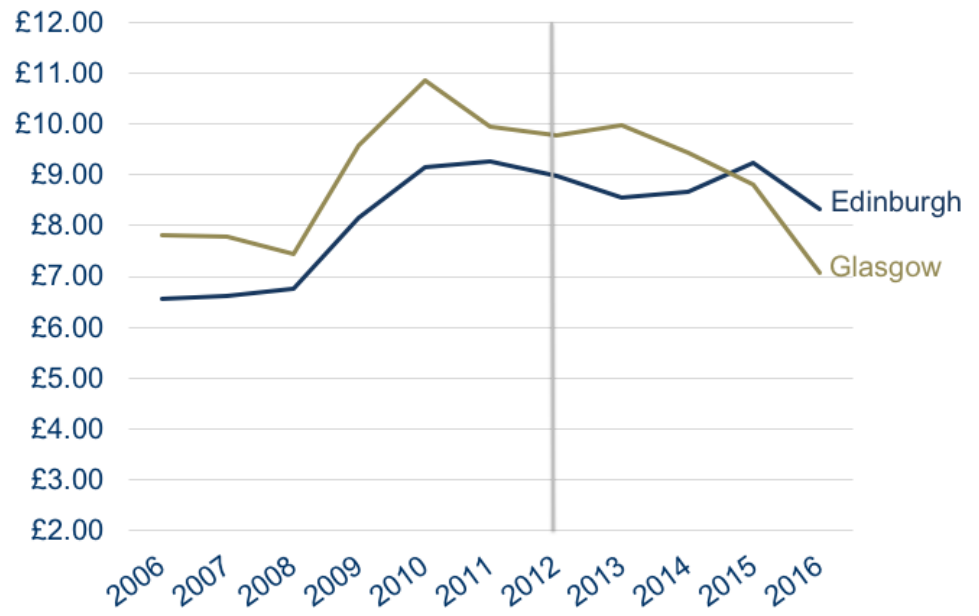

Figure 10: Operating cost per passenger Edinburgh and Glasgow airports 2006-2016 (2016 prices)

Sources: Annual reports and accounts for Glasgow International Airport Ltd and Edinburgh International Airport Ltd 2005/6 to 2016 and CAA airport traffic statistics 2006 to 2016 
The period before 2012 was associated with relative traffic stagnation and rising operating costs with the latter explained by the fact that the provider of terminal air navigation services had decided that the costs of their operation at both airports would be charged to the airport rather than to the airlines directly. Both airports have been quite successful post-2012 apparently exercising much greater financial discipline on their operations with Glasgow out-performing Edinburgh by achieving a $28 \%$ real terms reduction in unit operating costs since 2012.

Private shareholders and investors in both airports, especially the new owners at Edinburgh, are likely to have been especially focussed on the profitability of their assets. Figure 11 compares the EBITDA margin over the period for both airports. Edinburgh achieves a consistently higher level of EBITDA margin over the period but with Glasgow narrowing the gap quite considerably between 2015 and 2016. Both airports have achieved quite respectable EBITDA margins by international standards and the ratios are rising. The average for European airports that handled 5 to 15 million passengers in 2015 was reported to be $56 \%$ ( $\mathrm{ACl}, 2017)$. Arguably, this reduction in unit costs and increase in profits post-2012 could be interpreted as an effect from added commercial pressure exercised by shareholders and investors on airport management to maximise returns.

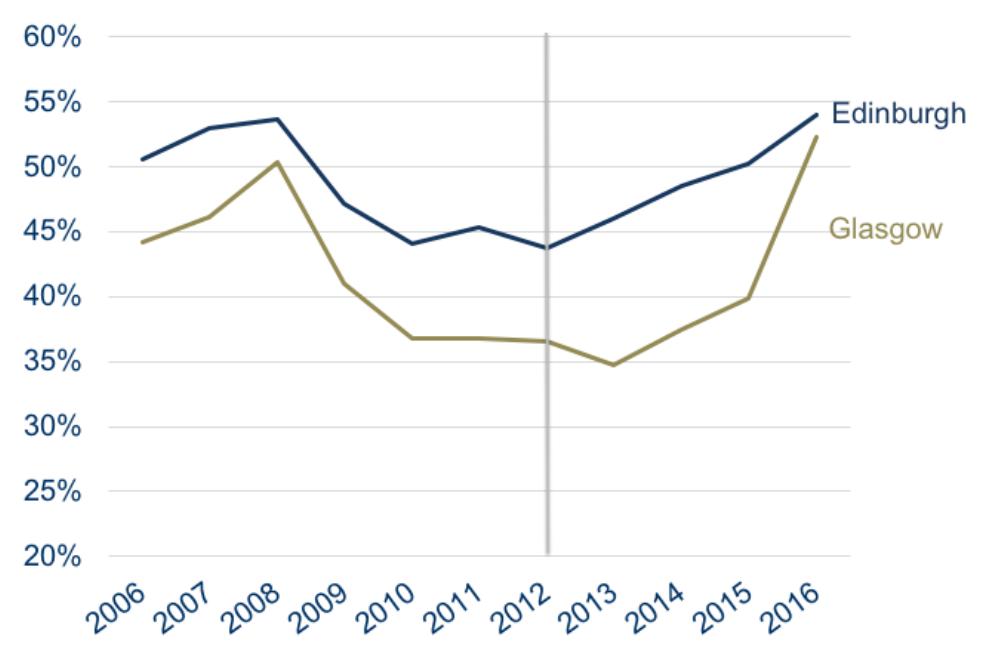

Figure 11: EBITDA margin Edinburgh and Glasgow airports 2006-2016

Sources:Annual reports and accounts for Glasgow International Airport Ltd and Edinburgh International Airport Ltd 2005/6 to 2016 and CAA airport traffic statistics 2006 to 2016 


\subsection{Service quality}

In competitive markets there are strong incentives on airports to maintain or enhance service levels and, with the development of an airport quality of service initiative by $\mathrm{ACl}$ in addition to the proliferation of online customer ratings platforms like Skytrax, many airports have become increasingly focussed on assessing service quality. However, if airports perceive there to be a low risk of losing market share to local rivals, then a temptation may be to maximise the returns to investors at the expense of funding investment to enhance the quality of assets and to improve service levels.

Unfortunately, a lack of sufficient data means that a detailed assessment of this dimension of performance at Glasgow and Edinburgh airports is not possible. Instead, the analysis draws together the limited evidence that is available. A crude indication of an improvement in service quality can be an increase in capital investment, assuming that this has been undertaken to make significant enhancements to the infrastructure and facilities provided (Figure 12).

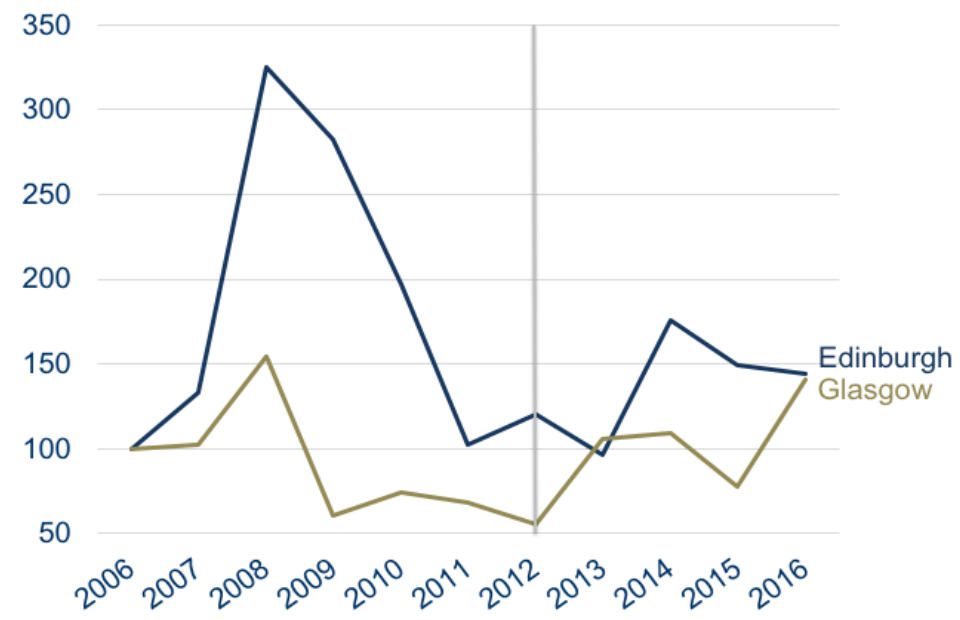

Figure 12: Indices of capital expenditure (nominal terms) at Edinburgh and Glasgow airports 2006-2016

Sources:Annual reports and accounts for Glasgow International Airport Ltd and Edinburgh International Airport Ltd 2005/6 to 2016 and CAA airport traffic statistics 2006 to 2016

The sudden spike in capital expenditure at Edinburgh in 2008 was in fact, partly due to costs incurred in the re-surfacing of the main runway in addition to other 
developments. Glasgow's capital expenditure cycle also peaked in 2008 largely driven by its "Sky Hub" extension. In Glasgow's case, the level of capital investment was generally lower, perhaps reflecting the fact that the airport's assets were overall, more mature and developed compared to Edinburgh. There is perhaps some indication that capital investment has risen since 2012 but this is by no means conclusive, and it is very difficult to interpret the trends in Figure 12, especially as the nature of airport capital investment is often lumpy, discrete and cyclical with phases of contraction often followed by expansion.

However, increases in capital investment are only one way in which service quality can be improved. Other areas, such as better employee training will not be reflected in such data and so indicators measuring passenger satisfaction can provide a broader perspective. Some limited examples of satisfaction rates are available from the $\mathrm{ACl}$ ASQ global service quality survey. Passengers rank their satisfaction from 1 (very poor) to 5 (excellent) and in Table 2 the scores out of 5 have been converted into percentages. Values in 2016 are considerably higher than in 2011 pre-divestment. At Edinburgh there was a decline in satisfaction followed by improvements which ICF (2016) suggests was due to the effects of short-term disruption before improved facilities came into operation. Table 2 also presents another measure of service quality, namely the percentage of departures leaving within 15 minutes of the scheduled time. For both the airports, performance has actually dropped rather than improved. However, this is a complex measure that is affected by many other variables that are outside of the control of airport management (including airline performance) and so, therefore, is much more difficult to interpret. It is important to realise that some capital expenditure post-2012 may not yet be reflected in these satisfaction figures given the lead times involved and possibly a lag-effect in terms of the impact on passengers' perception of service quality.

Year Passenger satisfaction (1) On-time performance (2) 


\begin{tabular}{lrrrr} 
& Edinburgh & Glasgow & Edinburgh & Glasgow \\
\hline 2006 & n/a & n/a & 73.6 & 74.7 \\
2007 & n/a & n/a & 72.9 & 74.1 \\
2008 & n/a & n/a & 76.9 & 75.4 \\
2009 & n/a & n/a & 82.4 & 82.4 \\
2010 & 80.0 & 77.2 & 76.8 & 76.9 \\
2011 & 82.0 & 78.0 & 83.2 & 83.0 \\
2012 & 83.8 & 79.6 & 84.0 & 83.4 \\
2013 & 82.0 & 79.2 & 84.4 & 83.3 \\
2014 & 82.1 & 80.8 & 81.8 & 82.1 \\
2015 & 85.6 & 82.0 & 78.5 & 76.3 \\
2016 & 85.8 & 81.8 & 73.1 & 75.2 \\
\hline
\end{tabular}

Table 2: $\quad$ Service quality measures at Edinburgh and Glasgow airport 2006-2016

Sources:Annual reports and accounts for Glasgow International Airport Ltd and Edinburgh International Airport Ltd 2010 to 2016, CAA on-time performance statistics 2006 to 2016 and ICF (2016).

\section{Conclusions and Policy Implications}

This paper offers a deeper and more contemporary insight into the nature of the competitive rivalry that exists between both airports. In particular, it has been found that there was a marked deviation in the relative level of prices charged for aeronautical services between both airports following separation. Both airports are compared by using two measures of price; average yield and published charges. The question remains as to which more accurately represents true pricing intention and strategy. Yield is an average price and incorporates revenues collected from all air transport and aircraft operations including those included within bespoke bilateral pricing agreements with airlines which generally fall outside of published tariff frameworks. However, it is impossible to determine the precise scale and scope of bespoke arrangements at both airports and hence whether one indicator of price is a more accurate representation than the other. In any case for Edinburgh, both published and yield-based measures have increased since 2012. In contrast, average yield at Glasgow over the same period had declined in real terms since 2012; by 2016 it was 18\% lower than Edinburgh's. There was a modest increase in the levels of Glasgow's published per passenger charges over the period relative to Edinburgh. But by 2017 , Glasgow's international and domestic charges were still $14 \%$ and $18 \%$ lower than those set by Edinburgh respectively. 
The nature of aeronautical pricing in this particular case appears to signal a noticeable shift and divergence in the route development strategies of both airports since separation. Under BAA, there appeared to have been a much closer coordination of route development between Glasgow and Edinburgh with both airports positioned to specialise in leisure and business markets respectively; a reflection to some extent of differences in relative price-elasticities in their core catchment areas. Since divestment, Edinburgh, due to the price-inelastic nature of its market increased its charges in real terms seemingly without fear of loss of market share to Glasgow.

Glasgow's market appears to exhibit a greater degree of price sensitivity and vulnerability and perhaps there is also recognition of a competitive threat posed by nearby Prestwick which may reflect an instinct to defend and grow market share by capping charges. Glasgow has not achieved the same level of success in attracting and retaining network airlines as Edinburgh has achieved with low cost carriers such as Ryanair and Norwegian. However, since 2012, it should be recognised that Glasgow achieved a higher rate of new destination growth than Edinburgh.

The expectation that both airports would maintain convergence on a path of lower charges did not materialise. So, ownership separation has generally not led to lower prices at both airports but to price divergence with airlines presented with a clear choice in diverse value propositions offered by both airports. Given the considerable growth in passenger volumes at Edinburgh since 2012, it is even doubtful as to whether aeronautical charges actually make a significant difference to most airline's route development choices and that its contribution to route development may have historically been exaggerated.

The fact that both airports have been unable to substantially improve yields from nonaeronautical sources suggests, therefore, that there may have been pressure exerted by shareholders on managers to leverage higher aeronautical revenues in order to maximise EBITDA. Indeed, in one respect divestment, as predicted by the Competition Commission, did enable both airports to achieve important real-terms reductions in unit operating costs after 2012. So, this in combination with an 
aggressive aeronautical charges strategy, especially in Edinburgh's case, accounts for the significant improvement in EBITDA between 2012 to 2016.

The paper cannot assess whether the delivery of capital investment was timely and cost-effective which would have been expected in a competitive market. However, it could be assumed that the scale and volume of capital investment represents a degree of commitment to service quality and improvement. Interestingly, it was found that capital expenditure, especially at Edinburgh, was higher in real terms before separation. This then raises an important question around whether there was pressure to focus on shareholder returns at the expense of increased investment in new infrastructure. It should, however, be recognised that Edinburgh airport has already committed itself to a significant scale of investment beyond 2016 (Edinburgh Airport, 2017). Indeed, both airports appear to have improved overall passenger satisfaction levels since 2012.

There are clearly important policy implications for both competition and supervisory authorities that stem from this paper with respect to the impact of ownership change on business strategy and whether airport competition is feasible or indeed desirable. This paper broadly supports the CMA expectation that ownership separation has indeed been beneficial for the airports and their airline and passenger customers. The main evidence here very tentatively suggests that different ownership will lead to a divergence in pricing and route development strategy that more closely reflects underlying market characteristics, costs may be reduced, and passenger satisfaction increased. However, such findings need to be confirmed with a more robust econometric analysis. Additionally, this paper has suggested that traffic development and air service choice may also be enhanced by separated ownership but in this case, more than with any other performance area considered here, the findings are very much linked to this specific case so the extent to which they can be generalised are perhaps quite limited.

Other limitations also have to be recognised. The time period is relatively short, and it is indeed possible that improvements particularly around capital investment may take 
additional years to materialise into improved levels of service quality. Furthermore, the timeframe of analysis straddles the 2008-2009 world recession, which adversely affected both airports' traffic volumes. Prestwick is excluded from the analysis, even though it will have had some effect on the Glasgow's route development and pricing strategy, and there has been no assessment of additional impacts that could have arisen post-2014, when Glasgow was sold-off by Heathrow Airport Holdings to AGS. Taking these factors into account could build on the unique evidence base presented here, but nevertheless this research has already provided a significant insight into the impact of airport ownership separation on airport competition.

\section{Acknowledgements}

The authors would like to thank Mr Francois Bourienne, Director Commercial, Glasgow Airport Ltd for his very valuable insights on aeronautical charging, route development and airport competition.

\section{References}

ACI (2017), Airport Networks and the Sustainability of Small Airports, Montreal: ACI. ACl-Europe (2014), Competition in the European Aviation Sector, Brussels: AClEurope.

ACl-Europe (2015), Airport Charges Survey 2014, Brussels: ACl-Europe.

ACl-Europe (2017), The Competitive Edge: Airports in Europe, Brussels: ACl-Europe. ACl-Europe (2018) Europe's airports report strong growth, but rising costs and emerging risks, press release, 19 June.

Adler, N. and Liebert, V. (2014), Joint impact of competition, ownership form and economic regulation on airport performance and pricing. Transportation Research Part A: Policy and Practice, 64, 92-109.

Bel, G. and Fageda, X. (2010), Privatization, regulation, and airport pricing: an empirical analysis for Europe, Journal of Regulatory Economics, 37, 142 - 161.

Bezerra, G. and Gomes, C. (2016). Measuring airport service quality: a multidimensional approach, Journal of Air Transport Management, 53, 85-93. 
Bottasso, A., Bruno, M., Conti, M. And Piga, C. (2017), Competition, vertical relationship and countervailing power in the UK airport industry, Journal of Regulatory Economics, 52(1), 37-62.

Bush, H. (2009), The development of competition in the UK airport market, Journal of Airport Management, 4(2): 114-24.

CAA (2014), CAA Passenger Survey Report 2013, London: CAA.

Chi-Lok, A. and Zhang, A. (2009), Effects of competition and policy changes on Chinese airport productivity: an empirical investigation, Journal of Air Transport Management, 15(4), 166-174.

CMA (2016), BAA airports: Evaluation of the Competition Commission's 2009 market investigation remedies, London: CMA.

Competition Commission (2009), BAA Airports Market Investigation, London: Competition Commission.

De Wit, J. and Zuidberg, J. (2016), Route churn: an analysis of low-cost carrier route continuity in Europe, Journal of Transport Geography, 50, 57-67.

Edinburgh Airport (2017), Edinburgh Airport Limited Annual Report and Financial Statements for the year ended 31 December 2016, Edinburgh: Edinburgh Airport.

Fichert, F. and Klophaus, R. (2011), Incentive schemes on airport charges theoretical analysis and empirical evidence from German airports, Research in Transportation Business and Management, 1(1), 71-77.

Forsyth, P. (2006), Airport competition: regulatory issues and policy implications, in Lee, D. (ed.), Competition Policy and Anti-Trust, Oxford: Elsevier.

Forsyth, P., Gillen, D., Mueller, J. and Niemeier, H.-M. (eds) (2010) Airport Competition, Farnham: Ashgate.

Graham, A. (2018) Managing Airports, $5^{\text {th }}$ edition, Abingdon: Routledge.

Graham, A (2006) Competition in airports, in Papatheodorou, A. (ed.), Corporate Rivalry and Market Power: Competition Issues in the Tourism Industry, London: I.B. Tauris.

Halpern, A. and Graham, A. (2016), Airport Marketing, Abingdon: Routledge. Ha, H., Wan, Y., Yoshida, Y. and Zhang, A. (2013), Airline market structure and airport efficiency: Evidence from major Northeast Asian airports. Journal of Air Transport Management, 33, 32-42.

IATA (2013), Airport Competition, IATA Economics Briefing No 11, Geneva: IATA. 
ICF (2016), Evaluation of the 2009 Competition Commission's BAA airports market investigation remedies, London: ICF.

Jones, O., Budd, L. and Pitfield, D. (2013), Aeronautical charging policy incentive schemes for airlines at European airports, Journal of Air Transport Management, 33, 43-59.

Lee, K. and Yu, C. (2018), Assessment of airport service quality: A complementary approach to measure perceived service quality based on Google reviews, Journal of Air Transport Management, 71, 28-44.

Lieshout, R., Malighetti, P., Redondi, R., and Burghouwt, G. (2016), The competitive landscape of air transport in Europe, Journal of Transport Geography, 50, 68-82.

Marques, R. (2011), Together or separately? The efficiency and market structure of Portuguese airports, Journal of Air Transport Management, 50(2),136-139.

Malina, R., Albers, S. and Kroll, N. (2012), Airport incentive programmes: a European perspective, Transport Reviews, 32(4), 435-53.

OECD (2014), Expanding Airport Capacity: Competition and Connectivity, Paris: OECD.

Oxera (2017), The Continuing Development of Airport Competition in Europe, London: Oxera.

Pagliari, R. (2005), Developments in the supply of direct international air services from airports in Scotland, Journal of Air Transport Management, 11(4), 249-257.

Route Shop (2018), Edinburgh Airport. Available at:

http://www.therouteshop.com/profiles/edinburgh-airport/ (accessed 1 August 2018) Scotti, D., Malighetti, P., Martini, G., and Volta, N. (2012), The impact of airport competition on technical efficiency: stochastic frontier analysis applied to Italian airport, Journal of Air Transport Management, 22, 9-15.

Smyth, A., Christodoulou, G., Dennis, N., Al-Azzawi, M., Campbell, J., (2012), Is air transport a necessity for social inclusion and economic development?, Journal of Air Transport Management, 22: 53-59.

Socorro, M., Betancor, O. and de Rus, G., (2018), Feasibility and desirability of airport competition: The role of product substitutability and airlines' nationality. Journal of Air Transport Management, 67, 224-231.

Starkie D. (2008), The Airport Industry in a Competitive Environment: A United Kingdom Perspective, Discussion paper No 2005-15, Paris, International Transport Forum. 
Sunday Herald (2015), Government drops plans for new air route. Available at: http://www.heraldscotland.com/business_hq/13198600.Government_drops_plans_fo r_new_air_route_fund/ (accessed 1 August 2018).

Thelle, M., Pedersen, T. and Harhoff, F. (2012), Airport Competition in Europe, Copenhagen: Copenhagen Economics.

Thelle, M. and Sonne, M. (2018), Airport competition in Europe, Journal of Air Transport Management, 67, 232-240.

Toms, M. (2004), UK regulation from the perspective of BAA plc, in Forsyth, P., Gillen, D., Knorr, A., Mayer, O., Niemeier, H. and Starkie D. (eds), The Economic Regulation of Airports, Farnham: Ashgate.

Transport Scotland (2018), Air Route Development. Available at: https://www.transport.gov.scot/public-transport/air-travel/air-route-development/ (assessed 1 August 2018).

Van Dender, K. (2007), Determinants of fares and operating revenues at US airports, Journal of Urban Economics, 62(2), 317-336.

Wiltshire, J. (2018), Airport competition: Reality or myth? Journal of Air Transport Management, 67, 241-248. 
- Increase in published and yield-based prices at Edinburgh since separation

- Limited effect of higher prices on traffic growth at Edinburgh

- Both published and yield-based charges lower at Glasgow compared to Edinburgh

- Charging strategy based on price-elasticities and maximisation of EBITDA

- Impact of separation on service levels and capital investment inconclusive 